\title{
CURRENT SITUATION AND PROSPECTS OF CEREAL CROPS GROWING IN UKRAINE
}

\section{Averchev O. V.}

\section{INTRODUCTION}

Under the auspices of the United Nations Food and Agriculture Organization (FAO), world leaders have adopted the agenda for Sustainable Development of Humanity until 2030, which was supported at the national level by Presidential Decree No. 722/2019 of 30.09.2019 «On Sustainable Development Goals of Ukraine for the period up to 2030 ». One of the primary goals of sustainable development is to eliminate the deficit of food, to recover from hunger, malnutrition and poverty. However, it is not only a duty to end hunger on the Earth, but also a complex and comprehensive concept that includes improving nutrition, achieving food security and improving sustainable development of agriculture and nutrition, sustainable use and management of natural resources, and the protection of genetic resources. The main goal of achieving food security for the population is to increase the yielding of cereal crops, which provide more than half of the daily calories that people need for their development and daily living activities ${ }^{1}$.

Increasing grain yielding is a strategically important task. However, it is known that there has not been a significant increase in the yield of cereal crops in recent years. In addition, the inefficient use of irrigated soils actualizes the problem of reducing the shortage of crop products. Therefore, at the present stage of resolving these issues is particularly acute.

To solve these complex problems, it is necessary to use new perspective cereal crops, their varieties (hybrids) with high genetic potential of productivity, and also to apply a complex of agrotechnical measures corresponding to the area of cultivation in each agro-ecological zone. Cereal crops are one of such prospects ${ }^{2}$.

The economic efficiency of cereal crops growing in southern Ukraine has not been sufficiently studied, and at the present stage, output of products

\footnotetext{
1 Постанова № 15/01 Президії національної академії аграрних наук України (протокол № 15 від 23 жовтня 2019 року).

2 Аверчев О.В. Організаційно - економічні аспекти інтенсифікації виробництва круп'яних культур. [навчальний посібник] / Аверчев О.В. - Херсон: ФОП Грінь Д.С., 2011.- 202 c.
} 
which requires less use of resources while maximizing use of potential of cultivated crops and regional features is a priority area.

The issues of increasing the economic efficiency of cereal crop yielding require further scientific justification and practical solution.

The status of problem study. Numerous scientific developments of such national scientists as V. Andriychuk, V. Boyko, P. Gaydutsky, P. Sabluk, O. Averchev and many others are devoted to studying various aspects of increasing the economic efficiency of crops growing, including cereal crops. However, the important aspects of improving yielding efficiency by improving cultivation technology, taking into account regional conditions, need more discussions. Solution of these questions will help to complement the theoretical, methodological and applied aspects of the formation of regional grain markets. This, in turn, will increase the level of application orientation of the problem and give the practice appropriate economic mechanism for the formation of market relations on the principles of supply and demand, restoring the competitiveness of grain yielding and the effective functioning of the market as a whole.

\section{Economic significance of cereal crops}

Agriculture has long become a business. In addition, the main task for farmers is to maximize profits by increasing revenues and reducing costs. Therefore, each agricultural crop is viewed through an economic prism, that is, how much money eventually can be obtained when it is grown on 1 ha.

Buckwheat, Panicum and rice are among the promising high-yielding cereal crops ${ }^{3}$.

In modern conditions of market relations, when the expediency of growing crops depends not only on the value of yield and quality of yielding, but also on demand, stable and high prices, buckwheat is one of the crops that can provide sustainable and high profits. Therefore, the most important task of agricultural production is to increase the buckwheat grain yielding ${ }^{4}$.

Buckwheat is a major cereal crop. Buckwheat has good taste, nutritional and dietary qualities and it is on first place according to the composition of the protein complex and nutritional value among other cereals. By physiological value, the buckwheat proteins are close to proteins of chicken eggs and milk. In the context of updating the issues of environmental yielding, it is important that the technological process of buckwheat growing

3 Постанова № 15/01 Президії національної академії аграрних наук України (протокол № 15 від 23 жовтня 2019 року).

4 Динаміка обсягів виробництва круп'яних культур в Херсонській області. / О.В. Аверчев, // Таврійський науковий вісник: збірник наукових праць. - Вип. 87. Херсон: Айлант, 2001. - С. 57-61. 
does not include the use of pesticides, which makes it possible to obtain completely environmentally friendly foodstuff.

The national economic importance of buckwheat is also lies in the fact that it is a valuable medicinal plant, one of the best honey plants, by-products of its production (chaff, straw) is a valuable feed in animal agriculture. Agrotechnical value of buckwheat is that it reduces the weediness of the fields, improves the physical properties of the soil, increases its fertility, and improves phytosanitary status. It is a good forecrop because it absorbs hard phosphorus and potassium compounds for self-feeding and leaves them in soil with plant residues. Buckwheat is also a replacement crop for the sowing of winter crops. In the southern region, it is grown in post-harvested sowings, as well as for green fodder and green fertilizer. Buckwheat intensively increases the green mass and can produce yields up to $20000 \mathrm{~kg} /$ ha in 50-60 days of vegetation. Buckwheat is a crop of waste-free growing technology ${ }^{5}$. In this regard, the problem of increasing the volume of buckwheat yielding in modern conditions is of particular importance.

Much attention is paid to the growing of buckwheat by farms that have constant orders from the producers of cereals, because it does not belong to the leading crops. This crop is considered as a valuable honey plant and a good forecrop to crop rotation for other crops.

Most farms grow buckwheat to support their own beekeeping, and grain is more commonly sold and processed in the region where it is grown. In areas where buckwheat sowings are located, buckwheat honey is a most popular kind of honey. The most characteristic is that every fourth part of the collected in CIS honey is buckwheat honey. One hectare of buckwheat sowing covers in general of 40-60 kg of honey, and under more favorable weather conditions $90-100 \mathrm{~kg}$, according to the Institute of Beekeeping. The importance of buckwheat as a honey plant is further enhanced by the fact that with the cultivation of fields, and most importantly with the development of new technologies, the honey flora is increasingly disappearing.

It is also used in fodder production, namely small grain, as well as offal, which are obtained during grain processing. Small, shrinked grain, as well as mill offal and flour dust, which are formed during the processing of grain, is used for feeding of livestock and poultry. Buckwheat chaff (50 feed units contains $100 \mathrm{~kg}$ of chaff) and silage from the green mass of buckwheat is a nutritious animal feed. Husk with the content of $40 \%$ of potassium oxide in

5 Аверчев О.В. Організаційно - економічні аспекти інтенсифікації виробництва круп'яних культур. [навчальний посібник] / Аверчев О.В. - Херсон: ФОП Грінь Д.С., 2011.- $202 \mathrm{c}$. 
ash remain during the processing of buckwheat at the peeling mills. It is used as valuable local potash manure and as raw material for potash production.

The most important argument in favor of the wide introduction of buckwheat to the agriculture in the Southern steppe of Ukraine is the resowing of buckwheat on irrigated areas. Buckwheat is one of the most promising crops for these purposes. A great reserve for increasing the yielding of this crop is resowing. The sowing area of the main crops has stabilized, and expanding the buckwheat and Panicum sowing areas at the expense of the spring-sown field is economically inexpedient.

It should be noted that buckwheat in economic terms is very profitable crop. With the yield of 500-700 kg / ha, all costs for its growing are paid off, and with the yield of $1500-2000 \mathrm{~kg} / \mathrm{ha}$, buckwheat becomes the most profitable crop. Moreover, the greater the area of its sowing is, the higher profitability of buckwheat is.

Earlier, buckwheat was considered a strategically important food product that had an impact on food security in the country. In recent years, many alternative types of cereals that can replace buckwheat have appeared in the domestic market of Ukraine, which is why this type of product affects the general food situation in the country. Price controls the level of consumption. So now, there is the following price situation: buckwheat costs $10 \%$ more than rice $^{6}$.

Consumer basket in Ukraine is calculated in such a way that consumption of buckwheat per year is $2 \mathrm{~kg} /$ person, of rice $-2.5 \mathrm{~kg} /$ person, and of Panicum it is $1 \mathrm{~kg} /$ person. In comparison with the European countries (Poland), the consumption of buckwheat is $75 \%$ and of rice is $65 \%$ lower than in Ukraine ${ }^{7}$.

Rice is the most important, most productive, most ancient and most caloric crop among all the cereals. It is grown on all continents of the world. The largest areas are given to rice, as to wheat and maize. The area of rice sowing has tripled in the last 100 years and now amounts to more than 150 million hectares. Rice has a higher potential yield compared to wheat of $800-1000 \mathrm{~kg} / \mathrm{ha}$, which provides an annual gross yield of almost 600 million tons. There are about 30 species of rice, but common rice (O. Sativa) is the most widespread. It is an annual plant with a height of $50-200 \mathrm{~cm}$, in Ukraine $-80-140 \mathrm{~cm}$.

${ }^{6}$ Аверчев О.В. Організаційно - економічні аспекти інтенсифікації виробництва круп'яних культур. [навчальний посібник] / Аверчев О.В. - Херсон: ФОП Грінь Д.С., 2011.- $202 \mathrm{c}$.

7 Динаміка обсягів виробництва круп'яних культур в Херсонській області. / О.В. Аверчев, // Таврійський науковий вісник: збірник наукових праць. - Вип. 87. Херсон: Айлант, 2001. - С. 57-61. 
The rice systems are located near the sea coasts and are in close proximity to the resort areas not only in Ukraine, but in most rice sowing countries of the world. In the early years, the technology of rice cultivation did not meet the requirements of ensuring ecological balance. Therefore, the scientists of the Institute of Rice of the National Academy of Agrarian Sciences of Ukraine (NAAS) carried out the important research and created a new environmentally friendly technology, taking into account all the requirements of environmental protection, which received positive conclusions of state expertise. The experience of the Rice Institute on addressing environmental issues has attracted the attention of foreign colleagues.

The main task of modern agricultural productivity, including rice yielding, is to obtain a high economically viable grain yield, which is largely facilitated by the cultivar. Rice growing as an intensive industry requires new varieties with high productivity, adapted to biotic and abiotic environmental factors, which in different agro-ecological conditions could give maximum profit ${ }^{8}$.

Nowadays, such valuable cereal crop as the Panicum are receiving insufficient attention, although it is characterized by high drought tolerance, which is quite positive with the gradual change of the climate over the last decade. And this crop, unlike buckwheat, provides fairly stable yields on the South Ukraine area, regardless of weather conditions ${ }^{9}$.

Panicum is one of the major crops in the world. This spring cereal is appreciated for its high taste qualities of the grain (millet). It is resistant to drought, it is a crop of short daylight, has a fast growing season. Due to these properties, it is often sown as a nutrimental.

However, Panicum has never held a leading role among crops in the agricultural sector of Ukraine. It is one of the major cereals of Ukraine, the value of which is determined by the almost waste-free use of processing products in the food, feed, pharmaceutical and microbiological industries, as well as the by the possibility of growing in post-harvested sowings, which ensures two yields and increase the yield per hectare. Unprocessed Panicum is used as a very valuable animal feed. The by-products that are received during the processing of grain into groats (flour, husk) are also feed. Straw and chaff are close to meadow hay by their qualities. Panicum is widely used as a replacement crop in the event of resowing of fallen winter and early spring crops, which is especially important for yield formation and income during a year. Panicum consist of $12 \%$ of

${ }^{8}$ Динаміка обсягів виробництва круп'яних культур в Херсонській області. / О.В. Аверчев, // Таврійський науковий вісник: збірник наукових праць. - Вип. 87. - Херсон: Айлант, 2001. - С. 57-61.

9 Кернасюк Ю.В. Зернові культури: тенденції і прогнози ринку / Агробізнес сьогодні. - 2017 р. - № 17(360) - С. 12-19. 
protein, $81 \%$ of starch, $3.5 \%$ of fat and $1-2 \%$ of fiber. The grain is rich with minerals, micro-elements, vitamins B1, B2, B5, B6, C, carotenoids and other physiologically active elements. Also, the crop contains a large amount of starch, so it is used for the production of alcohol ${ }^{10}$.

The underestimation of the value of Panicum growing is erroneous. Panicum is a high-yielding cereal crop. By adhering to the technology of growing, it yields grains over $5000 \mathrm{~kg} / \mathrm{ha}$. Yields are often higher than other cereals.

\section{Dynamics of cereal crops growing in Ukraine}

According to the State Statistics Service of Ukraine, the area of cereal crops during the research period was undulating, except for rice sowings, which is related to the specificity of the technology of the crop growing (Table 1).

Table 1

Yielding of buckwheat, Panicum and rice in Ukraine for 2015-2018

\begin{tabular}{|c|c|c|c|}
\hline Crop & $\begin{array}{c}\text { Harvested area, } \\
\text { tons of ha }\end{array}$ & $\begin{array}{l}\text { Gross output in weight after } \\
\text { processing, thousand tons }\end{array}$ & $\begin{array}{c}\text { Yield, } \\
\text { kg per ha }\end{array}$ \\
\hline \multicolumn{4}{|c|}{2015} \\
\hline Buckwheat & 127,7 & 128,1 & 1000 \\
\hline Panicum & 112,8 & 213,2 & 1890 \\
\hline Rice & 11,7 & 62,5 & 5340 \\
\hline \multicolumn{4}{|c|}{2016} \\
\hline Buckwheat & 153,7 & 176,4 & 1150 \\
\hline Panicum & 107,7 & 189,7 & 1760 \\
\hline Rice & 12,0 & 64,7 & 5390 \\
\hline \multicolumn{4}{|c|}{2017} \\
\hline Buckwheat & 185,3 & 180,4 & 970 \\
\hline Panicum & 56,1 & 84,4 & 1500 \\
\hline Rice & 12,7 & 63,9 & 5050 \\
\hline \multicolumn{4}{|c|}{2018} \\
\hline Buckwheat & 113,3 & 137,0 & 1260 \\
\hline Panicum & 54,8 & 80,5 & 1460 \\
\hline Rice & 12,6 & 69,2 & 5490 \\
\hline
\end{tabular}

Buckwheat occupies the largest areas among the major studied cereal crops. Buckwheat crop area was larger than the harvested area of Panicum from $11.7 \%$ in 2015 to $70 \%$ in 2017 and larger than the sowing area of rice from $109.2 \%$ in 2015 to $106.9 \%$ in 2017.

10 Аверчев О.В. Організаційно - економічні аспекти інтенсифікації виробництва круп'яних культур. [навчальний посібник] / Аверчев О.В. - Херсон: ФОП Грінь Д.С., 2011.- 202 c. 
Rice crop areas have remained virtually unchanged over the years as they are linked to the check system of growing, and rice growing under drip irrigation is only gaining momentum. Gross output after processing during 2015 and 2016 was the highest during Panicum growing and amounted to 213.2 thousand tons and 189.7 thousand tons respectively, which is $70.7 \%$ more than the gross output of rice after processing in 2015 and $66.3 \%$ more in 2016.

Due to the sharply reduced sowing area by $49.9 \%$ in 2017 and $48.6 \%$ in 2018 compared to 2015, the large difference in gross output in weight after processing between rice and Panicum was practically leveled. The gross output of Panicum was the highest for all years of research in 2015 and 2016 and in the same years, it was the highest among all the studied crops. From 2017, the maximum gross output was received from buckwheat growing at 137.0 thousand tons in 2018 and 180.4 thousand tons in 2018. Among the studied cereal crops, traditionally the most productive is rice that is connected with its biological potential. The maximum yield of rice was obtained in 2018 at the level of $5490 \mathrm{~kg} / \mathrm{ha}$, which is 3.7 times higher than the average Panicum yield and 4.4 times higher than the average buckwheat yield in Ukraine.

According to official statistics, the buckwheat harvested area in Ukraine in 2018 decreased, depending on the studied year from 14.4 thousand hectares to 72 thousand hectares. The maximum area of sowings which was harvested was in 2018. At the same time, the average yield increased by $290 \mathrm{~kg} / \mathrm{ha}$ and amounted to $1260 \mathrm{~kg} / \mathrm{ha}$, the gross output exceeded 137.0 thousand tons, which is more than in 2015 by $7.0 \%$.

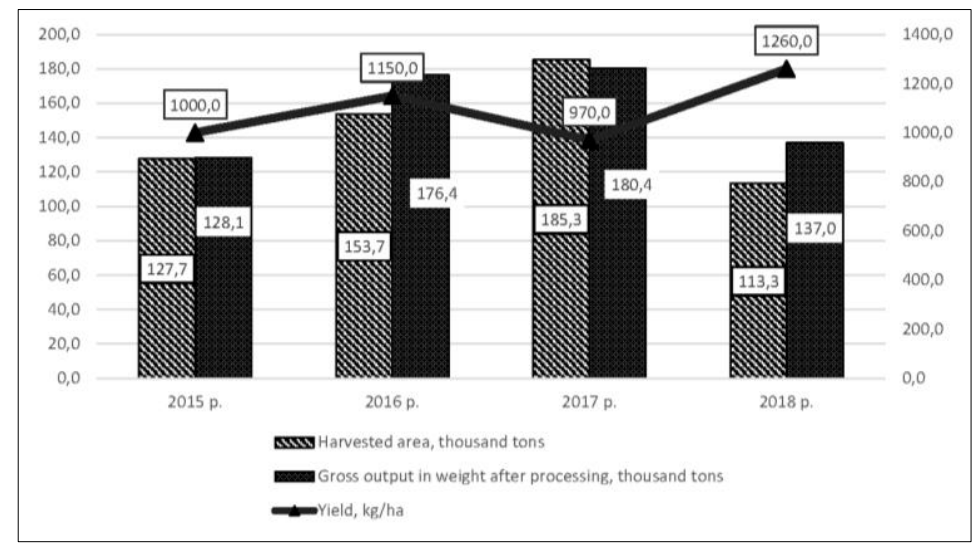

Fig. 1. Indicators of buckwheat yielding in Ukraine 
The dynamics of buckwheat grain yielding in Ukraine can be described as undulating. The main reasons for the decrease in the gross output of buckwheat are unfavorable climatic conditions (drought), high costs for its growing relative to other crops, non-compliance of agro-technology and lack of financial investments in crop growing and, as a consequence, decrease of its productivity. Thus, the largest gross output of buckwheat in mass after processing reached in 2017 and amounted to 180.4 thousand tons.

It should be noted that Ukraine is on the third place in the world for buckwheat growing (9\%) after China (39\%) and Russia $(22 \%)^{11}$.

The situation is better with rice. The harvested area in 2018 was 12.6 thousand hectares, which is more by 0.6 thousand hectares in 2016 and by 0.9 thousand hectares in 2015. At the same time, the yield increased by $490 \mathrm{~kg} / \mathrm{ha}$ in comparison with 2017 and is $5490 \mathrm{~kg} / \mathrm{ha}$ at a gross output of 69.2 thousand tons. (Fig. 3).

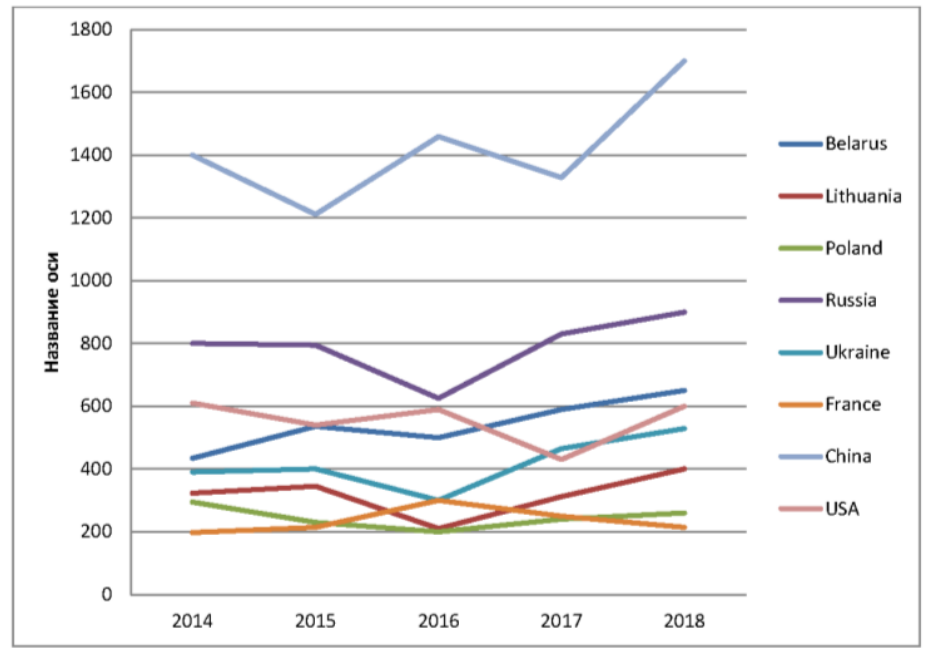

Fig 2. The main producers of buckwheat in the world

11 Кернасюк Ю.В. Зернові культури: тенденції і прогнози ринку / Агробізнес сьогодні. - 2017 р. - № 17(360) - С. 12-19. 


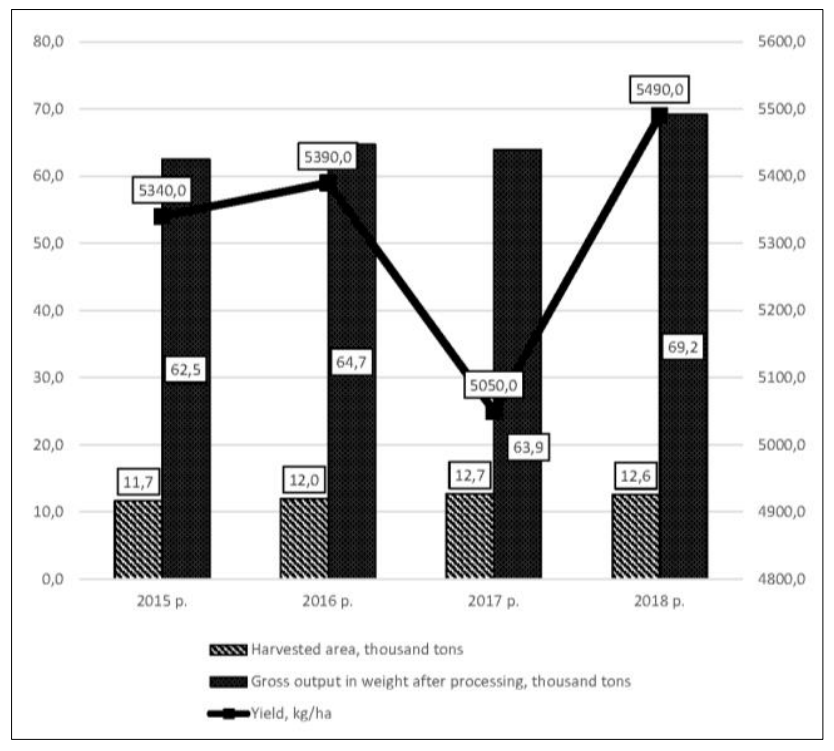

Fig. 3. Indicators of rice yielding in Ukraine

Rice, along with buckwheat, is the leader of cereals consumption among the population of Ukraine. The overall level of domestic rice yielding accounts for only $35 \%$ of the market's needs, so this market is now importdependent (Fig. 4). As a result of rice imports, there was a significant increase in 2014, amounting to 84.0 thousand tons. And the lowest exports in 2015-2016 was 43980 thousand tons. The average export value in relation to 2016/17 is 45790 thousand tons. Analyzing, it is seen that rice imports have unstable indicators. The largest importers are India, Pakistan, Kazakhstan, and Vietnam.

Although by 2014, the situation was somewhat different: rice checks located in the Crimea made it possible to grow a larger share of what was needed on the territory of the country.

In 2018, Ukrainian agrarians harvested 80.5 thousand tons of Panicum, which is $4.6 \%$ less than in the previous year (Table 4). In particular, agricultural enterprises harvested 52.0 thousand tons of Panicum, which is $5.9 \%$ more than in 2017, and households harvested 28.5 thousand tons $(-20.2 \%)$. 
Table 2

Rice import to Ukraine

\begin{tabular}{|c|c|c|c|}
\hline $\begin{array}{c}\mathbf{2 0 1 4} \\
\text { 84 thousand tons }\end{array}$ & $\begin{array}{c}\mathbf{2 0 1 5 / 2 0 1 6} \\
\mathbf{4 3} 980 \text { thousand } \\
\text { tons }\end{array}$ & $\begin{array}{c}\mathbf{2 0 1 6 / 2 0 1 7} \\
\mathbf{4 5} \mathbf{7 9 0} \text { thousand } \\
\text { tons }\end{array}$ & $\begin{array}{c}\mathbf{2 0 1 7 / 2 0 1 8} \\
\mathbf{5 3 ~ 4 5 6} \\
\text { thousand tons }\end{array}$ \\
\hline India $32450 \mathrm{t}$ & $\begin{array}{c}\text { India } 16345 \\
\mathrm{t}, 43,3 \%\end{array}$ & $\begin{array}{c}\text { India } 16426 \\
\mathrm{t}, 35,9 \%\end{array}$ & India \\
\hline Pakistan $21569 \mathrm{t}$ & $\begin{array}{c}\text { Pakistan } 13245 \\
\mathrm{t}, 35,5 \%\end{array}$ & $\begin{array}{c}\text { Pakistan } 14626 \\
\mathrm{t}, 31,9 \%\end{array}$ & Pakistan \\
\hline Vietnam $13450 \mathrm{t}$ & $\begin{array}{c}\text { Kazakhstan } 5900 \\
\mathrm{t}, 9,5 \%\end{array}$ & $\begin{array}{c}\text { Kazakhstan } 6052 \\
\mathrm{t}, 13,2 \%\end{array}$ & Kazakhstan \\
\hline & $\begin{array}{c}\text { Thailand } 4320 \\
\mathrm{t}, 3,9 \%\end{array}$ & $\begin{array}{c}\text { Vietnam } 4449 \\
\mathrm{t}, 9,7 \%\end{array}$ & Thailand \\
\hline & $\begin{array}{c}\text { Vietnam } 2100 \\
\mathrm{t}, 3,5 \%\end{array}$ & $\begin{array}{c}\text { Thailand } 2174 \\
\mathrm{t}, 4,7 \%\end{array}$ & \\
\hline & Russia $809 \mathrm{t}, 1,6 \%$ & Russia $899 \mathrm{t}, 2,0 \%$ & \\
\hline & Italy $435 \mathrm{t}, 1,3 \%$ & Italy $535 \mathrm{t}, 1,2 \%$ & \\
\hline & & USA $440 \mathrm{t}, 1,0 \%$ & \\
\hline
\end{tabular}

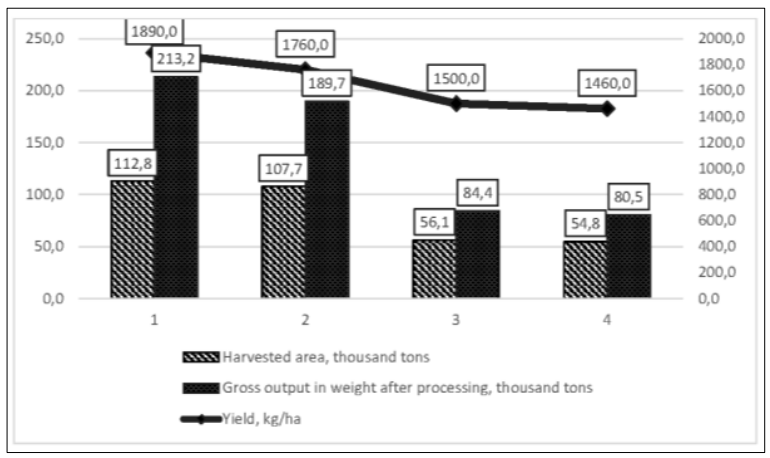

Fig. 4. Indicators of Panicum yielding in Ukraine

The decrease in the volume of Panicum yielding is due to both the reduction of acreage under it and the decrease in the average crop yield. Last year, 54.8 thousand hectares were sown with Panicum, which is $2.3 \%$ less than in 2017. The average yield decreased by $2.7 \%$ and amounted to $1460 \mathrm{~kg} / \mathrm{ha}$.

It should be noted that the Panicum yielding in Ukraine (for 2005-2018 $1260 \mathrm{~kg} / \mathrm{ha})$ significantly exceeds the world average yielding $(850 \mathrm{~kg} / \mathrm{ha})$ of 
this grain, as well as the yielding in India $(91 \mathrm{~kg} / \mathrm{ha})$ - the world leader of Panicum yielding ${ }^{12}$.

The structure of domestic consumption of Panicum consists of $20 \%$ of food and $72 \%$ fodder use of it.

According to the estimates of grain market experts, it is planned to reduce the area under buckwheat in Ukraine, because buckwheat growing technology provides certain specific features. It is necessary to take into account the norms of buckwheat sowings, biology of nutrition, growth and flowering for high yields. That is why it was given the status of a capricious crop.

In total, there are currently 30000 ha of rice irrigation systems in Ukraine. In recent years, rice has been sown on an area of about 13000 hectares, and when restoring such systems, especially in the Odessa region, it is possible to increase the area under rice by another 2000 hectares. The general climatic conditions and water resources of Ukraine allow growing rice on an area of more than 100000 hectares.

Experts say that at this stage it is necessary to increase the area of rice crops. The culture itself is not easy to grow; it requires a special climate heat and humidity. In Ukraine, farmers buy seeds at the only rice institute in Ukraine (Antonovka village, Skadovsk).

Rice cereals of domestic production are made exclusively from grown grain, since there are no state stocks of rice in Ukraine. It contains the required range of valuable indicators of quality, which is not inferior to the imported ones, but far exceeds them by some, including culinary ones. However, under market conditions, it has to be equated with price of lowcalorie crop. The cheapest third-grade cereals produced from the grain of state stocks of exporting countries after long-term storage or from its mixture with freshly-produced grain come from abroad to Ukraine in large quantities. Quality of such grain is much worse than quality of domestic grain, both in terms of biochemical parameters, look and smell, but due to the cheap and low purchasing power of the population, it dictates a general decrease in prices in the market ${ }^{13}$.

Growing of cereal crops is concentrated in certain regions of Ukraine, where the climatic conditions, soil composition, etc. are the best for them.

In Ukraine, the forest-steppe and Polissya zones are the most favorable for the buckwheat growing, where natural and climatic conditions allow protecting crops from arid winds, which allows plants to grow better during vegetation and have higher yields.

Soils and conditions of other regions are also suitable for growing buckwheat, but because of low yields the sowing areas of this crop are insignificant. According to the results of 2018, the largest gross buckwheat

\footnotetext{
12 Офіційний сайт Держкомстату України [Електронний ресурс]. - Режим доступу : http://www.ukrstat.gov.ua/

13 Динаміка обсягів виробництва круп'яних культур в Херсонській області. / О.В. Аверчев, // Таврійський науковий вісник: збірник наукових праць. - Вип. 87. Херсон: Айлант, 2001. - С. 57-61.
} 
harvests were received in Zhytomyr (28.0 thousand tons), Khmelnitsky (18.6 thousand tons), Sumy (11.6 thousand tons), Kyiv (10.7 thousand tons), Kharkiv (10.4 thousand tons) and Vinnitsa (10.1 thousand tons) oblasts. Transcarpathian farmers $(1920 \mathrm{~kg} / \mathrm{ha})$, Kyiv and Khmelnytskyi $(1560 \mathrm{~kg} / \mathrm{ha})$ received the highest yields. For comparison, the yield of this crop in the Kherson region is $980 \mathrm{~kg} / \mathrm{ha}$ with a gross output of 0.5 thousand tons.

About $52.0 \%$ of the sowing areas of Panicum are concentrated in the Southern region (Zaporizhzhya, Kherson, Mykolaiv, Dnipropetrovsk and Odessa regions), the main producers of this crop are Kharkiv (12.6\%), Zaporizhzhia (10.9\%), Dnipropetrovsk and Donetsk (9.5\%), Mykolaiv $(9.0 \%)$ regions. The highest average annual yield indicators have Cherkasy (2350 kg/ha), Poltava (2280 kg/ha), Kharkiv (2010 kg/ha), Vinnytsia (1910 kg/ha) and Lviv (1900 kg/ha). Buckwheat crops are mainly located in 10 regions of the North, West and Central regions) $-75.3 \%$ of the total area, $48.8 \%$ of which are the farms of Sumy, Khmelnytsky, Kharkiv, Vinnytsia and Chernihiv regions. The main producers of this crop are: Khmelnytskyi $12.9 \%$, Sumy $-12.8 \%$, Kharkiv $-10.2 \%$, Vinnytsia $-9.0 \%$ and Kiev oblast $-8.2 \%$, and the highest average annual buckwheat yield indicators have Kyiv (1260 kg/ha), Vinnytsia (1100 kg/ha), Kharkiv (1090 kg/ha), Khmelnitsky (1040 kg/ha), Sumy and Cherkasy (1020 kg/ha) 3. Therefore, those regions that have larger areas are not always the largest producers of cereals (rice, Panicum and buckwheat) and the highest average annual yield indicators doesn't have farms where larger areas occupied by the crop, which means that the structure of sowings areas, production and yields do not match, although these indicators are interdependent.

\section{CONCLUSIONS}

Analysis of the dynamics of buckwheat, Panicum and rice growing in Ukraine showed that the situation is not stable. Sowings areas of cereal crops during the study period were undulating, except for rice crop that is related to the specificity of cultivation technology. A similar situation was observed in the analysis of yielding of the studied crops, which in turn was reflected in the gross output of crops.

Experts estimate that the low level of economic efficiency of the industry was the result of a number of factors, including deterioration of socio-economic conditions of the farms, lack of a state program of development and support of cereal crops growing, insufficient provision of means of growing and in this regard, non-compliance of the requirements of the technology of crops growing, and also increase of production prime cost (increase of prices for pesticides, mineral fertilizers, fuel and lubricants, seeds, etc.).

In order to obtain high and sustainable yields of buckwheat, Panicum and rice and increase economic efficiency, it is recommended to introduce not only the latest growing technologies, but also to deepen specialization, concentration of cereal crops growing and to develop ways of improving the 
economic relations between enterprises of the production and processing of grain of cereal crops.

The problems of development of the grain economy and the market of cereal crops can be solved on the basis of the relevant law of Ukraine, according to which the state restores the contract system for grain in terms of rational needs and strategic stocks, implements the mechanism of intervention procurement, and creates the appropriate infrastructure in the grain market. Under this scheme, the State Directorate for Production and Sale of Grain and Grain Processing, subordinated to the Government, should be established in Ukraine, the activity of which will be controlled by representatives of producers and organizations within its administrative council.

\section{SUMMARY}

The economic efficiency of cereal crops growing in southern Ukraine has not been sufficiently studied, and at the present stage, a priority area in crop growing is yielding of grain, which requires less use of resources while maximizing use of the potential of grown crops and regional features.

The article deals with the dynamics of growing of buckwheat, Panicum and rice. It is established that among studied crops buckwheat occupies the largest areas. Buckwheat crop area was larger than the harvested area of Panicum from $11.7 \%$ in 2015 to $70 \%$ in 2017 and larger than the sowing area of rice from $109.2 \%$ in 2015 to $106.9 \%$ in 2017.

Gross output in weight after processing during 2015 and 2016 was the highest during Panicum growing and amounted to 213.2 thousand tons and 189.7 thousand tons respectively, which is $70.7 \%$ more than the gross output of rice after processing in 2015 and $66.3 \%$ more in 2016.

Due to the sharply reduced sowing area by $49.9 \%$ in 2017 and $48.6 \%$ in 2018 compared to 2015, the large difference in gross output in weight after processing between rice and Panicum was practically leveled. The gross output of Panicum was the highest for all years of research in 2015 and 2016 and in the same years, it was the highest among all the studied crops. From 2017, the maximum gross output was received from buckwheat growing at 137.0 thousand tons in 2018 and 180.4 thousand tons in 2018. Among the studied cereal crops, traditionally the most productive is rice that is connected with its biological potential. The maximum yield of rice was obtained in 2018 at the level of $5490 \mathrm{~kg} / \mathrm{ha}$, which is 3.7 times higher than the average Panicum yield and 4.4 times higher than the average buckwheat yield in Ukraine.

\section{REFERENCES}

1. Постанова № 15/01 Президії національної академії аграрних наук України (протокол № 15 від 23 жовтня 2019 року).

2. Аверчев О.В. Організаційно - економічні аспекти інтенсифікації виробництва круп'яних культур. [навчальний посібник] / Аверчев О.В. Херсон: ФОП Грінь Д.С., 2011.- 202 с. 
3. Динаміка обсягів виробництва круп'яних культур в Херсонській області. / О.В. Аверчев, // Таврійський науковий вісник: збірник наукових праць. - Вип. 87. - Херсон: Айлант, 2001. - С. 57-61.

4. Сільське господарство України у 2017 р.: Статистичний збірник К.: Державна служба статистики України, Статистичний збірник.

5. Сільське господарство України у 2018 р.: Статистичний збірник К.: Державна служба статистики України, Статистичний збірник

6. Сільське господарство України у 2019 р.: Статистичний збірник К.: Державна служба статистики України, Статистичний збірник

7. https://graintrade.com.ua/ru/novosti/zakupivelni-tcini-na-zernov-ukraini-na-14-veresnya-2018-roku.html

8. Офіційний сайт Держкомстату України [Електронний ресурс]. Режим доступу : http://www.ukrstat.gov.ua/

9. Кернасюк Ю.В. Зернові культури: тенденції і прогнози ринку / Агробізнес сьогодні. - 2017 р. - № 17(360) - С. 12-19.

\section{Information about the author:} Averchev O. V.,

Doctor of Agricultural Science, Professor, Prorector for Scientific Work and International Activity, State Higher Educational Institution "Kherson State Agricultural University" 23, Stritenskaya str., Kherson, Ukraine 